\title{
TRADITIONAL ENVIRONMENTAL KNOWLEDGE AND GIFTED STUDENTS AS TWO IMPORTANT SOURCES OF SOCIAL MEMORY: GIFTED STUDENTS' ATTITUDES TOWARDS TRADITIONAL KNOWLEDGE
}

\author{
Ilker Ugulu \\ Faculty of Education, \\ Usak University, \\ Usak, Turkey
}

\begin{abstract}
:
Traditional ecological knowledge (TEK) can be defined as cumulative knowledge, beliefs, and practices transmitted from generation to generation, related to people's relationship with the environment. This study aims to determine the attitudes of gifted students towards traditional environmental knowledge and to examine them in terms of various variables such as age, class and gender. The study group of the research consists of 120 gifted/talented students (67 girls, 53 boys) studying at Manisa Science and Art Center. "Traditional Knowledge Attitude Scale (TKAS)" developed by Ugulu (2013) was used in the study. The t-test and ANOVA test were used to determine whether students' attitudes towards science showed a significant difference in terms of independent variables of the study. According to the results of the research, when the average of the students' attitudes towards traditional knowledge according to their grade levels were evaluated, it was seen that the eighth-grade students' attitude scores were the highest. In terms of gender, it was concluded that the attitude scores of female students were higher than male students. As a result of the statistical comparison of the attitude scores of the gifted students according to the independent variables of the study, it was concluded that the difference between the averages in terms of grade level and age variables was not significant, but there was a significant difference in favour of girls in terms of gender ( $p$ $<0.05$ ).
\end{abstract}

Keywords: special education, gifted students, gender, age, attitude

\section{Introduction}

Traditional ecological knowledge (TKS) can be defined as cumulative knowledge, beliefs, and practices transmitted from generation to generation, related to people's relationship

${ }^{i}$ Correspondence: email ilkerugulu@gmail.com 
with the environment (Hansen \& VanFleet, 2003). The main thing here is the continuity of knowledge transfer within the community (Yorek, Sahin \& Ugulu, 2010; Ugulu, 2015a). This concept is important in terms of seeing the basis of the problems of human-nature relations. TKS research aims to reveal the ecological knowledge of each of the local communities living in many parts of the world, which has shown a unique development line (Ugulu \& Aydin, 2011). Environmental ethics are seen in agriculture, forestry, hunting and animal husbandry activities of traditional societies that have been influenced by religion, folklore and archaic beliefs (Correa, 2001). The destruction of the environment caused by modern man, especially the destruction of forests or trees, has inevitably brought the conceptions of the traditional consciousness about nature to the agenda (Yorek et al., 2010). The destruction caused by civilization, progress, industry, technology and resource-oriented modern consciousness has increased the importance of TKS, which is related to traditional environmental consciousness and has brought the issue of transferring the traditional consciousness to modern times by updating the environmental or nature consciousness (Ugulu \& Erkol, 2013; Yorek, Ugulu \& Aydin, 2016). From this point of view, alternative perspectives can be produced to the exploitation-oriented development strategies of modern societies based on the industrial economy. Transfer of traditional ecological knowledge; proverbs, idioms, phrases, etc. language material, narratives, beliefs, rituals, and the traditional world view that emerges in their sum (Ugulu et al., 2008; Ugulu, 2009).

Although TKS research started earlier, the use of TKS terminology can be traced back to the 1980s. The use of TKS is as old as the hunter-gatherer periods of humanity (Berkes, 1993; Berkes, 2008). Studies carried out within the framework of concepts such as Ecological Anthropology, Deep Ecology, and Environmental Determinism have focused on spiritual elements in local cultures and environmental relations, but systematic TKS research has focused on various branches of local environmental knowledge in traditional societies based on subsistence economic models by keeping projections on people who are part of the ecosystem (Erkol \& Ugulu, 2014). This local information system can find many different application areas such as livelihood technologies, traditional medicine, ethnobotany, use of water resources. As Berkes (1993) stated, in addition to ecology; Traditional knowledge studies with a rich background in agriculture, pharmacology and botany are evaluated in many different fields. Compared to these fields, the study of indigenous knowledge in ecology is relatively new (Correa, 2001).

Gifted students have a great potential to contribute to the development of many fields with their characteristics (Ugulu, 2019). The correct orientation of these features is also very important in terms of scientific and social development. Therefore, the point of view of gifted individuals on TKS, which can be considered as a part of social memory, is important in this respect. 


\subsection{Gifted education in Turkey}

The education of the gifted in Turkey is carried out in three groups as private schools, private classes and after-school programs (Ugulu, 2020). Examples of private schools are science high schools, sports high schools and conservatories; Examples of after-school programs are Gifted Education Programs and Science and Arts Centers (SACs). Special classes for gifted students are only seen in private sector schools (Sak et al., 2015).

The problem of flexibility in the education of gifted students in Turkey is at the forefront of an important problem. For example, according to the National Education legislation, gifted students can skip only one class during the whole academic year, and the education system does not offer them the opportunity to take courses from universities or upper classes (Sak, 2013). For this reason, the opportunities created for the development of gifted students who attend regular classes are not enough. For this reason, after-school programs and especially SACs play an important role in the education of gifted students (Ugulu, 2015b).

\subsection{Science and Art Centres}

Science and Art Centers (SACs), which were established in 1995 to raise gifted students in primary, secondary and high schools in the period remaining from normal education, to develop their potential, are currently the nationwide after-school program model. As of 2019, there are 139 SACs in various provinces and districts of Turkey (Turkish Ministry of National Education, 2019). The SAC model aims to offer enriched programs during extracurricular hours without separating gifted students from their normal peers. Apart from formal education, SACs provide education to students at various levels on certain days of the week (Karabulut, 2010). In these centres, gifted students mostly work on social and scientific projects and produce solutions to real-life problems (Orbay et al., 2010).

\subsection{Objectives}

Studies have shown that students' attitudes affect their behaviours, their determination about the decisions they will make, and their preferences on these issues. For example, it is seen that students with higher scientific background and literacy at school are more successful in their decisions. From this point of view, it is of great importance to ensure the active participation of gifted individuals, who are defined as the most important human resource of a country, in the environmental issue, which is among the most important agenda items of today and the future. Therefore, training and employment of gifted individuals in the environment, as in other social areas, will make significant contributions to the development and progress of our country. In this direction, this study aims to determine the attitudes of gifted students towards traditional environmental knowledge and to examine them in terms of various variables such as age, class and gender. 


\section{Material and Methods}

\subsection{Research Design}

This study, which was conducted to determine the attitudes of gifted students towards traditional environmental knowledge and to determine whether these attitudes differ according to gender, age and class variables, is a descriptive single survey model (Yorek et al. 2008).

\subsection{Sampling}

The study group of the research consists of 120 gifted/talented students ( 67 girls, 53 boys) studying at Manisa Science and Art Center. The distribution of these students according to their class levels and age groups is presented in Table 1 and Table 2.

Table 1: Distribution of students according to gender and age levels

\begin{tabular}{|c|c|c|c|c|c|c|c|c|c|}
\hline & \multicolumn{2}{|c|}{10} & \multicolumn{2}{|c|}{11} & \multicolumn{2}{|c|}{12} & \multicolumn{2}{|c|}{13} \\
\hline & & $\mathrm{f}$ & $\%$ & $f$ & $\%$ & $f$ & $\%$ & $f$ & $\%$ \\
\hline \multirow{2}{*}{ Gender } & G & 1 & 100 & 20 & 57,1 & 31 & 57,4 & 15 & 50,0 \\
\hline & B & - & - & 15 & 42,9 & 23 & 42,6 & 15 & 50,0 \\
\hline \multicolumn{2}{|l|}{ Total } & 1 & 100 & 35 & 100 & 54 & 100 & 30 & 100,0 \\
\hline
\end{tabular}

Table 2: Distribution of students according to grades

\begin{tabular}{|l|c|c|c|c|}
\hline & \multicolumn{2}{|c|}{ Grade } & \multirow{2}{*}{ Total } \\
\cline { 2 - 4 } & $\mathbf{5}^{\text {th }}$ grade & $\mathbf{6}^{\text {th }}$ grade & $\mathbf{7}^{\text {th }}$ grade & 120 \\
\hline $\mathrm{f}$ & 45 & 34 & 41 & 100 \\
\hline$\%$ & 37,5 & 28,3 & 34,2 & \\
\hline
\end{tabular}

\subsection{Data Analysis}

In the study, to determine the attitudes of gifted students towards traditional environmental knowledge, the data obtained from the TKAS scale were transferred to the computer environment and analyzed with the SPSS 24.00 package program. Whether the students' attitudes towards the environment differed significantly in terms of the independent variables of the study was investigated using the $t$-test for bivariate features and the ANOVA (One Way Analysis of Variance) test for features with more than two variables. If there was a significant difference between the groups as a result of the ANOVA test, the source of the difference was determined by the Scheffe test. In addition, the Pearson correlation coefficient was calculated to determine whether there was a relationship between the sub-dimensions of the scale depending on the data collected.

\subsection{Data Collection Tool}

“Traditional Knowledge Attitude Scale (TKAS)" developed by Ugulu (2013) was used in the study. As a result of the validity and reliability analysis performed on the scale for this study, it was seen that the scale had 3 sub-dimensions. Considering the results obtained from the students in the study group, the consistency between the items for these three dimensions was re-examined and the Cronbach's alpha reliability coefficient 
of the "Attitudes Toward Traditional Medicine Knowledge" sub-dimension (4 items) was 0.85, and the "Attitudes Toward Plant and Animal Knowledge" sub-dimension ( 6 items) reliability coefficient was 0.86 , and the reliability coefficient of the "Attitudes Toward General Environmental Knowledge" sub-dimension (5 items) was 0.76. In the scale consisting of 15 items in total, participants are asked to evaluate themselves on a 4-point Likert-type scale ranging from " $1=$ disagree" to " $4=$ agree". In addition, in the personal information form part of the test, there are questions about the independent variables of the research such as the name, surname, age, gender and class of the participants. Cronbach Alpha values for the sub-dimensions of the scale are presented in Table 3.

Table 3: Cronbach Alpha Values of Traditional Knowledge Attitude Scale

\begin{tabular}{|l|c|c|}
\hline Sub-dimension & Item & Cronbach Alpha Value \\
\hline Attitudes Toward Traditional Medicine Knowledge & 4 & 0.85 \\
\hline Attitudes Toward Plant and Animal Knowledge & 6 & 0.86 \\
\hline Attitudes Toward General Environmental Knowledge & 5 & 0.76 \\
\hline Traditional Knowledge Attitude Scale & 15 & 0.82 \\
\hline
\end{tabular}

\section{Results}

Determining the attitudes of gifted students towards traditional environmental knowledge and the variables affecting these attitudes is important in terms of environmental education to be applied to these students and ensuring active participation of students in the solution of environmental problems in our country. In this context, in line with the determined research purpose, the average scores of gifted students from TKAS and its sub-dimensions and statistical analyzes of these scores are presented in tables in this section.

The answers given by the students in the research group to the TKAS were evaluated and it was seen that the students reached a general average of 52.75 on the scale, which was evaluated as a total of 60 points. When the average attitude scores for the sub-dimensions were examined, it was seen that they achieved an average of 21.05 in the "Attitudes Toward Traditional Medicine Knowledge" sub-dimension, 14.35 in the "Attitudes Toward Plant and Animal Knowledge" sub-dimension, and 17.25 in the "Attitudes Toward General Environmental Knowledge" sub-dimension. The averages of the students' attitude scores regarding TKAS and its sub-dimensions are presented in Table 4 .

Table 4: Traditional Knowledge Attitudes of Gifted Students

\begin{tabular}{|l|c|c|c|c|c|c|}
\hline Sub-dimension & $\mathbf{N}$ & $\begin{array}{c}\text { Item } \\
\text { Number }\end{array}$ & Mean & $\begin{array}{c}\text { Std. } \\
\text { Dev. }\end{array}$ & Max & Min \\
\hline $\begin{array}{l}\text { Attitudes Toward Traditional } \\
\text { Medicine Knowledge }\end{array}$ & 120 & 6 & 21.05 & 3,10 & 23 & 17 \\
\hline $\begin{array}{l}\text { Attitudes Toward Plant and } \\
\text { Animal Knowledge }\end{array}$ & 120 & 4 & 14.35 & 2,91 & 16 & 13 \\
\hline Attitudes Toward General & 120 & 5 & 17.25 & 3,77 & 19 & 16 \\
\hline
\end{tabular}




\begin{tabular}{|l|c|c|c|c|c|c|}
\hline \hline Environmental Knowledge & & & & & & \\
\hline Total & 120 & 15 & 52.75 & 6.11 & 57 & 47 \\
\hline
\end{tabular}

When the attitude scores of the students according to their grade levels were examined, the attitude scores of the fifth-grade students were determined as 51.7, the attitude scores of the sixth-grade students as 52.6 and the attitude scores of the seventh-grade students as 53.9. These findings show that there is a slight increase in students' attitudes towards traditional knowledge with the increase in their grade levels. The scores of students' attitudes towards traditional knowledge determined according to their grade levels are presented in Table 5.

Table 5: Traditional Knowledge Attitude Levels According to Grades

\begin{tabular}{|l|c|c|c|}
\hline Grade & N & X & ss \\
\hline 5 & 45 & 51.7 & 5,05 \\
\hline 6 & 34 & 52.6 & 6,54 \\
\hline 7 & 41 & 53.9 & 7,05 \\
\hline Total & 120 & 52.75 & 11,75 \\
\hline
\end{tabular}

When the attitude scores of the students in the research group towards traditional knowledge are evaluated according to the age variable, it is seen that the mean attitude scores of the students in different age groups have values close to the general average $(X=52.75)$. An attitude score of 52 for a student in the 10-year-old group and an attitude score of 51.7 for a student in the 11-year-old group is below the general average. In addition, it was determined that the attitude scores of the students in the 12-year-old group were almost the same as the general average with a value of 51.6, and the average of the attitude scores of the students in the 13-year-old group was above the general average with a value of 53.9. When these values are evaluated together, it is seen that the attitudes of gifted students towards traditional knowledge increase relatively with increasing age. The scores of students' attitudes towards traditional knowledge, determined by age groups, are presented in Table 6.

Table 6: Traditional Knowledge Attitude Levels According to Gender and Age

\begin{tabular}{|c|c|c|c|c|c|c|c|c|c|c|c|c|c|}
\hline \multirow{2}{*}{\multicolumn{2}{|c|}{ Age }} & \multicolumn{3}{|c|}{10} & \multicolumn{3}{|c|}{11} & \multicolumn{3}{|c|}{12} & \multicolumn{3}{|c|}{13} \\
\hline & & $\mathbf{N}$ & $X$ & SS & $\mathbf{N}$ & $X$ & SS & $\mathbf{N}$ & $X$ & SS & $\mathbf{N}$ & $X$ & SS \\
\hline \multirow{2}{*}{ Gender } & G & 1 & 52 & - & 20 & 51.72 & 5,32 & 31 & 52.66 & 5,37 & 15 & 53.96 & 4,61 \\
\hline & B & - & - & - & 15 & 51,68 & 4,01 & 23 & 52,54 & 4,32 & 15 & 52.84 & 3,85 \\
\hline \multicolumn{2}{|l|}{ Total } & 1 & 52 & - & 35 & 51.70 & 6,15 & 54 & 51.60 & 6,32 & 30 & 53.90 & 5,32 \\
\hline
\end{tabular}

Independent sample t-Test analysis was performed in order to determine whether the students' attitude scores towards traditional knowledge and the attitude scores they obtained from the TCAS sub-dimensions showed a significant difference according to gender. The results of the analysis showed that the difference between the students' attitude scores according to their gender was statistically significant $(p<0.05)$. In addition, 
this difference was found to be in favour of female students with an average of 55.68 (Table 7).

Table 7: t-Test Analysis of TKAS Scores According to Gender

\begin{tabular}{|l|c|c|c|c|c|}
\hline Gender & N & X & SS & sd & p \\
\hline G & 67 & 55.68 & 5,88 & \multirow{2}{*}{120} & \multirow{2}{*}{$.003^{*}$} \\
\hline B & 53 & 51.31 & 4,89 & & \\
\hline
\end{tabular}

ANOVA (one-way ANOVA) analysis was conducted to determine whether the attitude scores of gifted students and the attitude scores they obtained from the sub-dimensions of TKAS showed significant differences according to the independent variables of class and age. It was determined that the general attitude scores of the students in the study group did not show a statistically significant difference according to both independent variables ( $p>0.05$ ). Statistical analyzes regarding the significance of the difference between the students' attitude scores determined according to the grade and age variables are presented in Table 8 and Table 9.

Table 8: ANOVA Analysis of TKAS Scores According to Class Levels

\begin{tabular}{|l|c|c|c|c|c|c|}
\hline Source & Sum of Squares & df & Mean Square & F & P & Sig. \\
\hline Between Groups & 16201,709 & 119 & 136,149 & \multirow{2}{*}{1,859} & \multirow{2}{*}{160} & \\
\cline { 1 - 5 } Within Groups & 506,264 & 1 & 253,132 & & \\
\hline Total & 16707,973 & 121 & & & & \\
\hline
\end{tabular}

Table 9: Findings on the relationship levels between the sub-dimensions

\begin{tabular}{|l|c|c|c|c|c|c|}
\hline Source & Sum of Squares & df & Mean Square & F & P & Sig. \\
\hline Between Groups & 16081,260 & 118 & 136,282 & \multirow{2}{*}{1,533} & \multirow{2}{*}{.210} & \\
\cline { 1 - 5 } Within Groups & 626,713 & 2 & 208,904 & & \\
\hline Total & 16707,973 & 120 & & & & \\
\hline
\end{tabular}

\section{Discussion}

The study aims to determine the attitudes of gifted students, who are thought to make significant contributions to science, scientific studies, sustainability and social development, towards traditional knowledge and to compare these attitudes according to variables such as class, gender and age. According to the results of the research, when the average of the students' attitudes towards traditional knowledge according to their grade levels were evaluated, it was seen that the eighth-grade students' attitude scores were the highest. In terms of gender, it was concluded that the attitude scores of female students were higher than male students. As a result of the statistical comparison of the attitude scores of the gifted students according to the independent variables of the study, it was concluded that the difference between the averages in terms of grade level and age variables was not significant, but there was a significant difference in favour of girls in terms of gender $(\mathrm{p}<0.05)$. 
Ugulu, Akkaya \& Erkol (2013) examined the attitudes of gifted students towards the environment and the demographic variables that affect it. According to the results of the research, when the average of the student's attitudes towards the environment is evaluated according to the grade level they are studying, it is seen that the attitude scores of the students studying in the 5th grade are slightly higher than the averages of the students studying in the 6th and 7th grades. However, when the scores of attitudes towards the environment are evaluated according to the age variable, it is seen that the scores of attitudes towards the environment decrease as the age of the students' increases. In terms of gender, it was concluded that female students' attitude scores were higher than male students. As a result of the statistical comparison of the environmental attitude scores of the students participating in the study according to the independent variables of the research, it was concluded that the difference between the averages was significant in favour of female students in terms of gender, but not significant in terms of grade level and age variables $(p<0.05)$. When the findings obtained by Ugulu, Akkaya \& Erkol (2013) are compared with the findings of the present study, there is dissimilarity in terms of attitude score according to class level and similarity in terms of the effect of gender on attitudes.

Important research in science and environmental education has approached students' concept research from a different age perspective (Trumber, 2001; Ugulu, Sahin \& Baslar, 2013). The results of all studies generally showed that although some concepts that children construct change over time, some alternative concepts do not change from kindergarten to university (Westbrook and Marek 1991). In this study, it was determined that high-grade students had higher attitudes towards traditional knowledge than lowergrade students. Freedman (1997) stated that laboratory education has a positive effect on students' attitudes towards science lessons. However, the number of laboratory experiments is decreasing at high levels as experiments become more complex and teachers do not prefer to experiment. It can be said that the enrichment programs implemented by the Science and Art Centers, which have an important role in the education of gifted students in Turkey, contributing to the positive change in students' attitudes towards science, knowledge, art and the environment. However, the attitudes of gifted students towards knowledge and science are closely related to the education they receive. Numerous studies with inclusive students support the findings that students start science studies with positive attitudes, but the situation declines rapidly towards middle school and high school (Farenga \& Joyce, 1998; Weinburgh, 1995). Swiatek and Lupkowski-Shoplik (2000) found that negative attitudes towards science increased with age from third to sixth grade.

In this study, there is a significant difference between male and female students' attitudes towards traditional knowledge. According to many studies conducted in different fields, the existence of gender-based differences in participation and achievement in science and attitudes towards science are widely accepted. Despite the evidence that gender differences exist in attitudes towards science and knowledge, it is unclear how these attitudes affect scientific processes and science outcomes (Simpson 
and Oliver 1990; Weinburgh 1995). Also, studies have shown that girls become less interested in science than boys as they get older (Catsambis 1995).

Less research has been done on gifted men than on gifted women in math and science. The reason for this situation can be shown as the fact that men pursue careers in these fields more than women (Curebal 2004). Various reasons are cited in the literature to explain why some talented women do not succeed or continue in science. These include lack of ability or effort, socialization of gifted students' perceptions of ability, selfefficacy in mathematics, science and technology, the effect of standardized tests, parents' and teachers' attitudes on performance, and future career plans (Stumpf and Stanley, 1996; Reis and Park 2001).

\section{Conclusion}

The results of the study showed that gifted students have different levels of attitudes towards traditional knowledge at different grade levels. The findings also showed that individual differences also affect attitudes, as advocated by contemporary educational approaches. Since boys and girls perceive themselves differently and have different expectations from the educational environment, the teacher should provide activities that will help meet specific gender needs. The educator should choose different classroom settings for students of different grade levels, and the teacher should provide activities to help meet specific needs.

Individuals who are effective in the emergence of environmental problems should also take part in the solution of these problems and should be brought to a sufficient level of awareness about what their responsibilities are. For this reason, effective environmental education should be carried out at every stage of education in our country. The results of this study have also shown that gifted students have a very important potential in terms of their attitudes towards the environment and traditional knowledge, both in terms of reaching the desired levels of environmental education in our country and in terms of developing and carrying out projects related to the protection and sustainability of the environment.

\section{Limitations}

This study is limited in many ways. First of all, only grade level, gender and age were determined as dependent variables in this study. The effects of the educational status of students and parents are excluded. Many educators believe that these factors can interact, influencing students' learning outcomes. The sample size is another limiting factor.

\section{Conflict of interest statement}

The author declares no conflicts of interests. 


\section{About the Author}

Dr. Ilker Ugulu is an associate professor at Special Education Department, Faculty of Education, Usak University, Turkey. His areas of expertise include Gifted Education, Biology Education, Environmental Education and Ecology.

\section{References}

Berkes, F. (1993). Traditional ecological knowledge in perspective. Traditional ecological knowledge: Concepts and cases. (Julian T. Inglis, Ed.). Ottawa: International Development Research Centre.

Berkes, F. (2008). Sacred ecology. New York: Routledge.

Catsambis, S. (1995). Gender, race, ethnicity, and science education in the middle class. Journal of Research in Science and Teaching, 32(3): 243-257.

Correa, C. (2001). Traditional knowledge and intellectual property: Issues and options surrounding the protection of traditional knowledge. Geneva: Quaker United Nations Office (QUNO).

Curebal, F. (2004). Gifted students' attitudes towards science and classroom environment based on gender and grade level, Unpublished Graduate Thesis, Ankara: Graduate School of Natural and Applied Sciences at METU.

Erkol, S. \& Ugulu, I. (2014). Examining biology teachers' candidates' scientific process skill levels and comparing these levels in terms of various variables. Procedia Social and Behavioral Sciences, 116:

4742-4747. http://dx.doi.org/10.1016/j.sbspro.2014.01.1019

Farenga, S. J. \& Joyce, B. A. (1998). Science-related attitudes and science course selection: A study of high-ability boys and girls. Roeper Reviews, 20: 247-251.

Freedman, M.P. (1997). Relationship among laboratory instruction, attitude toward science, and achievement in science knowledge. Journal of Research in Science and Teaching, 34: 343-357.

Hansen, S. \& VanFleet, J. (2003). Traditional knowledge and intellectual property: A handbook on issues and options for traditional knowledge holders in protecting their intellectual property and maintaining biological diversity. Washington, DC: American Association for the Advancement of Science (AAAS).

Orbay, M., Gokdere, M. \& Tereci, H. \& Aydin, M. (2010). Attitudes of gifted students towards science depending on some variables: A Turkish sample. Scientific Research and Essays, 5(7): 693-699.

Reis, S. M. \& Park, S. (2001). Gender differences in high-achieving students in math and science. Journal for the Education of the Gifted, 25: 52-73.

Sak, U. (2013). Education programs for talented students' model (EPTS) and its effectiveness on gifted students' mathematical creativity. Educational Sciences, 38: 51-61. 
Sak, U., Ayas, M. B., Sezerel, B. B., Opengin, E., Ozdemir, N. N. \& Gurbuz, S. D. (2015). Gifted and Talented Education in Turkey: Critics and Prospects. Turkish Journal of Giftedness Education, 5(2): 110-132.

Simpson, R. D. \& Oliver, J. S. (1990). A summary of major influences on attitude toward and achievement in science among adolescent students. Science Education, 74(1): 118.

Stumpf, H. \& Stanley, J. C. (1996). Gender-related differences on the College Board's advanced placement and achievement tests, 1982-1992. Journal of Educational Psychology, 88: 353-364.

Swiatek, M. A. \& Lupkowski-Shoplik, A. (2000). Gender differences in academic attitudes among gifted elementary school students. Journal for the Education of the Gifted, 23: 360-377.

Trumber, R. (2001). A cross-age study of junior high school students' conceptions of basic astronomy concepts. International Journal of Science Education, 23 (11): 1111-1123.

Turkey Ministry of Education 2019. Ministry of Education statue. Retrieved from http://www.meb.gov.tr/mevzuat

Ugulu, I. (2009). Determination of retention of students' knowledge and the effect of conceptual understanding. Biotechnology \& Biotechnological Equipment, 23(1): 14-18.

Ugulu, I., Sahin, M., \& Baslar, S. (2013). High school students' environmental attitude: Scale development and validation. International Journal of Educational Sciences, 5(4): 415-424.

Ugulu, I. (2013). Confirmatory factor analysis for testing validity and reliability of traditional knowledge scale to measure university students' attitudes. Educational Research and Reviews, 8 (16): 1399-1408.

Ugulu, I. \& Aydin, H. (2011). Research on students' traditional knowledge about medicinal plants: Case study of high schools in Izmir, Turkey. Journal of Applied Pharmaceutical Science, 1 (9): 43-46.

Ugulu, I. \& Erkol, S. (2013). Environmental attitudes of biology teacher candidates and the assessments in terms of some variables. NWSA-Education Sciences, 8(1): 79-89.

Ugulu, I., Akkaya, Z. \& Erkol, S. (2013). An investigation on environmental attitudes of gifted students and the assessments in terms of some demographic variables. NWSA-Education Sciences, 8(4): 400-410. http://dx.doi.org/10.12739/NWSA.2013.8.4.1C0595

Ugulu, I. (2015a). A quantitative investigation on recycling attitudes of gifted/talented students. Biotechnology \& Biotechnological Equipment, 29: 20-26. http://doi.org/10.1080/13102818.2015.1047168

Ugulu, I. (2015b). Development and validation of an instrument for assessing attitudes of high school students about recycling. Environmental Education Research, 21(6): 916942. http://doi.org/10.1080/13504622.2014.923381

Ugulu, I. (2019). Efficacy of recycling education integrated with ecology course prepared within the context of enrichment among gifted students. International Journal of 
Educational Sciences, 26(1-3), 49-58. https://doi.org/10.31901/24566322.2019/26.1$\underline{3.1086}$

Ugulu, I. (2020). Gifted students' attitudes towards science. International Journal of Educational Sciences, 28(1-3). 7-14. https://doi.org/10.31901/24566322.2020/28.1$\underline{3.1088}$

Ugulu, I., Aydin, H., Yorek, N. \& Dogan, Y. (2008). The impact of endemism concept on environmental attitudes of secondary school students. Natura Montenegrina, 7(3): 165-173.

Weinburgh, M. (1995). Gender differences in student attitudes toward science: A metaanalysis of literature from 1970 to 1991. Journal of Research in Science Teaching, 32: 387-398.

Westbrook, S. L., Marek, E. A. (1991). A cross-age study of student understanding of the concept of diffusion. Journal of Research in Science Teaching, 28: 649-660.

Yorek, N., Aydin, H., Ugulu, I., \& Dogan, Y. (2008). An Investigation on Students' Perceptions of Biodiversity. Natura Montenegrina, 7 (3), 175-184.

Yorek, N., Ugulu, I., Sahin, M. \& Dogan, Y. (2010). A qualitative investigation of students' understanding about ecosystem and its components. Natura Montenegrina, 9 (3): 973-981.

Yorek, N., Sahin, M. \& Ugulu, I. (2010). Students' representations of the cell concept from 6 to 11 grades: Persistence of the "fried-egg model". International Journal of Physical Sciences, 5(1): 15-24.

Yorek, N., Ugulu, I., \& Aydin, H. (2016). Using self-organizing neural network map combined with ward's clustering algorithm for visualization of students' cognitive structural models about aliveness concept. Computational Intelligence and Neuroscience, Article ID 2476256, 1-14. http://dx.doi.org/10.1155/2016/2476256 
Author(s) will retain the copyright of their published articles agreeing that a Creative Commons Attribution 4.0 International License (CC BY 4.0) terms will be applied to their work. Under the terms of this license, no permission is required from the author(s) or publisher for members of the community to copy, distribute, transmit or adapt the article content, providing a proper, prominent and unambiguous attribution to the authors in a manner that makes clear that the materials are being reused under permission of a Creative Commons License. Views, opinions and conclusions expressed in this research article are views, opinions and conclusions of the author(s). Open Access Publishing Group and European Journal of Education Studies shall not be responsible or answerable for any loss, damage or liability caused in relation to/arising out of conflicts of interest, copyright violations and inappropriate or inaccurate use of any kind content related or integrated into the research work. All the published works are meeting the Open Access Publishing requirements and can be freely accessed, shared, modified, distributed and used in educational, commercial and non-commercial purposes under a Creative Commons Attribution 4.0 International License (CC BY 4.0). 